\title{
Inhalt, Vol. 9, No. 4, 1986
}

\section{Contents}

Impressum 182

Multiples Myelom

Bartl, R. und Fateh-Moghadam, A., München

Die Diagnose des multiplen Myeloms

Sonderbände 195

Löffler, H.; Gassmann, W. und Haferlach, T, Kiel,

Pralle, H., Gießen

Vergleich der Stadieneinteilungen des Plasmozytoms. . . 196

Ludwig, H., WienlÖsterreich

Die Klinik des multiplen Myeloms 202

Barlogie, B. und Alexanian, R., Houston, Tex./USA

Therapie des resistenten und rezidivierten multiplen

Myeloms 210

Neuigkeiten für die klinische Praxis I214

Vertretbare therapeutische Risiken bei soliden Tumoren

Hossfeld, D. K., Hamburg

Vertretbare Risiken bei der kurativen Therapie bösarti-

ger Erkrankungen 215

Brunner, K. W., BernlSchweiz

Vertretbare Risiken bei der adjuvanten Therapie

Neuigkeiten für die klinische Praxis II 223

Nagel, G.A. und Wander, H.-E., Göttingen

Verantwortbare Risiken bei der Wahl der palliativen

Chemotherapie 225

Jungi, W.F., St. GallenlSchweiz

Risiken der alternativen Krebsbehandlung 231

Kurzmitteilungen (Wander et al.) 236

Hinweise für Autoren 238

Kurzmitteilungen (Mönchetal.)

Buchbesprechungen 242

Die oben aufgeführten Arbeiten wurden anläßlich der Gemeinsamen Jahrestagung der Österreichischen und Deutschen Gesellschaft für Hämatologie und Onkologie in Wien, Oktober 1985, vorgetragen.

Zusammengestellt von: D. Lutz, Ludwig-Boltzmann-Institut für Leukämieforschung, Wien.

Teil I wurde in der ONKOLOGIE 2/April 1986 publiziert. 
Imprint182

Multiple Myeloma

Bartl, R. and Fateh-Moghadam, A., Munich

Diagnosis of Multiple Myeloma 183

Special Editions 195

Löffler, H.; Gassmann, W. and Haferlach, T., Kiel,

Pralle, H., Giessen

Comparison of Staging Systems for Multiple Myeloma . . 196

Ludwig, H., Vienna!Austria

The Clinical Symptoms of Multiple Myeloma 202

Barlogie, B. and Alexanian, R., Houston, Tex. I USA

Therapy of Primary Resistant and Relapsed Multiple

Myeloma 210

News for Clinical Practice I 214

Acceptable Therapeutic Risks in Solid Tumors

Hossfeld, D.K., Hamburg

Acceptable Risks in the Curative Therapy of Malignant

Diseases 215

Brunner, K. W. , Bern/Switzerland

Acceptable Risks in Adjuvant Therapy 218

News for Clinical Practice II 223

Nagel, G.A. and Wander, H.-E., Göttingen

Considerations about Risks and Safety in Palliative

Chemotherapy 225

Jungi, W. F. , St. Gallenl Switzerland

Risks of Alternative Cancer Treatment

Short Communications (Wander et al.)

Instructions for Authors 238

231

Short Communications (Mönch et al.)

236

Book Reviews 242

The above mentioned lectures have been presented in the Gemeinsame Jahrestagung der

Österreichischen und Deutschen Gesellschaft für Hämatologie und Onkologie in Vienna,

October 1985.

Compiled by D.Lutz, Ludwig-Boltzmann-Institut für Leukämieforschung, Vienna. Part I was published in ONKOLOGIE 2/April 1986.

Beilagenhinweis: Einem Teil dieser Ausgabe liegt das Supplement 1/1986 «EPIRUBICIN» bei. Bibliographischer Hinweis: Inhaltsverzeichnisse dieser Zeitschrift erscheinen regelmäßig in current contents ${ }^{\circledR}$ sowie in anderen bibliographischen Diensten. 